\title{
First ecological report of bat diversity present in Sierra de Navachiste protected area, Sinaloa, Mexico.
}

\section{Primer informe ecológico de la diversidad de murciélagos presente en área protegida Sierra de Navachiste, Sinaloa, México.}

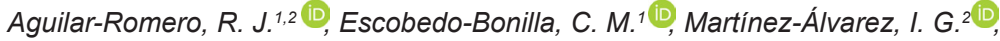 \\ Ley-Quiñónez, C. P. ${ }^{1,3}$ (D) Hart, C. E. (iD), Zavala-Félix, K. A. ${ }^{1}$ (D) Leal-Moreno, R. ${ }^{1}$ (D) Suzán, G. ${ }^{4}$ (D) \\ Aguirre, A. A. ${ }^{5}$ (D) Zavala-Norzagaray, A. A. ${ }^{1,3 *}$ (D)
}

${ }^{1}$ Instituto Politécnico Nacional, CIIDIR- SIN, Guasave, Sinaloa, México. ${ }^{2}$ Universidad Autónoma de Occidente, Guasave, Sinaloa, México. ${ }^{3}$ nvestigación, Capacitación y Soluciones Ambientales y Sociales AC Tepic, Nayarit, México. ${ }^{4}$ Universidad Nacional Autónoma de México, Instituto de Ecología. Ciudad de México, México. ${ }^{5}$ Universidad George Mason, Departamento de Ciencias y Políticas Ambientales. Fairfax, Virginia, Estados Unidos.

Cite this paper/Como citar este artículo: Aguilar-Romero, R. J., Escobedo-Bonilla, C. M., MartínezÁlvarez, I. G., Ley-Quiñónez, C. P., Hart, C. E., Zavala-Félix, K. A., Leal-Moreno,R., Suzán, G., Aguirre,A. A., Zavala-Norzagaray, A. A. (2022). First ecological report of bat diversity present in Sierra de Navachiste protected area, Sinaloa, Mexico. Revista Bio Ciencias 9, e1208. doi: https://doi.org/10.15741/revbio.09. $\underline{\mathrm{e} 1208}$

\section{A B S T R A C T}

In Mexico, studies on bats have reported the presence of eight families and a total of 140 species, of which seven families and 55 species are reported for the state of Sinaloa. However, the Sierra de Navachiste, México is a natural protected area of state jurisdiction registered as an area subject to Ecological Conservation. studies on bat populations in this area are scarce or nonexistent, resulting in their environmental needs, current threats and the impact they have at population level being unknown. Despite finding a low species richness (five species), the migratory species Leptonycteris yerbabuenae was caught in Sierra de Navachiste. This bat is included on the IUCN red list

\section{Article Info/Información del artículo}

Received/Recibido: June 01 2021.

Accepted/Aceptado: December 06 2021.

Available on line/Publicado: January $18^{\text {th }} 2022$.

\section{RES U M E N}

En México se ha reportado la presencia de ocho familias y un total de 140 especies de murciélagos, de las cuales, siete familias y 55 especies se encuentran en el Estado de Sinaloa. Sin embargo, existen lugares como el área natural protegida de jurisdicción estatal "Sierra de Navachiste" registrada como área sujeta a Conservación Ecológica, donde los estudios sobre las poblaciones de murciélagos son escasos o inexistentes. Como consecuencia, se desconocen sus necesidades ambientales y las amenazas a las que se enfrentan sus poblaciones. Pese a registrarse una baja riqueza de especies en el presente estudio (cinco especies), se reporta la especie migratoria Leptonycteris yerbabuenae. Este murciélago está incluido en la lista roja de la IUCN (Unión Internacional para la Conservación de la Naturaleza) como especie "vulnerable", y en México figura como especie de "protección especial". La especie $L$. yerbabuenae es considerada una mutualista clave dentro del ecosistema debido a su función como polinizador de 
(International Union for the Conservation of Nature) as a "vulnerable" species, and in Mexico it is listed as "Special protection" species. This bat is considered a keystone mutualist within the ecosystem due to its function as pollinator of the dominant columnar cacti and spreading its seeds though fruit consumption. These activities promote the dispersal of these plants and maintains the structure and health of the ecosystem. Due to the importance of the Sierra Navachiste as a refuge for at least five bat species, including one migratory and protected species, it is necessary to establish a management plan in order to protect the chiroptera community that depends on it.

\section{KEY WORDS}

Bats, conservation, ecology, Leptonycteris yerbabuenae, Northwest of Mexico.

\section{Introduction}

The Order Chiroptera is one of the most diverse and widely distributed vertebrate groups on the planet. Bats represent almost a quarter of all mammals (Hutson et al., 2001), with more than 1400 species (Simmons \& Cirranello, 2020; Zachos, 2020), and they are the second most diverse group after the Order Rodentia (Solari \& Baker, 2007).

Bats play a key trophic role being both prey and predatory species; presenting a very broad trophic spectrum that includes blood, insects, nectar, pollen, fruits and floral tissues. These habits provide diverse ecosystem services, such as pest control, seed dispersal, pollination and energy recycling (GalindoGonzález, 1998; Vaughan et al., 2011).

In Mexico, studies on bats have reported the presence of eight families and a total of 140 species (RivasCamo et al., 2020), of which seven families and 55 species are reported for the state of Sinaloa. However, studies on bat populations in this area are scarce or nonexistent (Almazán-Catalán et al., 2015). This result in lack of knowledge on their environmental needs, current threats and their impact at population level (Hutson et al., 2001). This makes it difficult to identify the ecological role of these organisms and their role los cactus columnares dominantes, y por esparcir sus semillas a través del consumo de sus frutos, promoviendo la dispersión de estas plantas, y manteniendo la estructura y salud del ecosistema. Debido a la importancia de la Sierra Navachiste como refugio de al menos cinco especies de murciélagos, incluida una especie migratoria y protegida, es necesario establecer un plan de manejo para proteger a las poblaciones de quirópteros que depende de ella.

\section{PALABRAS CLAVE}

Murciélagos, conservación, ecología, Leptonycteris yerbabuenae, Noroeste de México.

\section{Introducción}

El Orden Chiroptera es uno de los grupos de vertebrados más diversos y ampliamente distribuidos del planeta. Los murciélagos representan casi una cuarta parte de todos los mamíferos (Hutson et al., 2001), con más de 1400 especies (Simmons \& Cirranello, 2020; Zachos, 2020), y son el segundo grupo más diverso después del Orden Rodentia (Solari \& Baker, 2007).

Los murciélagos juegan un papel trófico clave al ser presas y especies depredadoras; presentando un espectro trófico muy amplio que incluye sangre, insectos, néctar, polen, frutos y tejidos florales. Estos hábitos brindan diversos servicios ecosistémicos, como el control de plagas, la dispersión de semillas, la polinización y el reciclaje de energía (GalindoGonzález, 1998; Vaughan et al., 2011).

En México, estudios sobre murciélagos han reportado la presencia de ocho familias y un total de 140 especies (RivasCamo et al., 2020), de las cuales se reportan siete familias y 55 especies para el estado de Sinaloa. Sin embargo, los estudios sobre las poblaciones de murciélagos en esta zona son escasos o inexistentes (Almazán-Catalán et al., 2015). Esto da como resultado una falta de conocimiento sobre sus necesidades ambientales, las amenazas actuales y su impacto a nivel poblacional (Hutson et al., 2001). Esto dificulta identificar el papel ecológico de estos organismos y su papel como mutualista clave en el ecosistema (Hornet et al., 1998; Menchaca et al., 2020). La adquisición de este conocimiento es fundamental, especialmente en áreas de importancia ecológica como el área protegida Sierra de Navachiste. 
as keystone mutualist in the ecosystem (Hornet et al., 1998; Menchaca et al., 2020). Acquiring this knowledge is essential, especially in areas of ecological importance such as the Sierra de Navachiste protected area.

Sierra de Navachiste, Mexico is classified as a Ramsar site forming part of the polygons for both the MacapuleNavachiste-San Ignacio lagoon system and the Santa María-Ohuira lagoon system (Zavala-Norzagaray et al., 2007) and is considered an ecological island, because it is surrounded by livestock farming and other agricultural activities.

In the region, 18 species of cacti have been identified on islands and the continental zone, where the dominant vegetation is Sternocereus thurberi and Pachycereus pecten-aboriginum (Saturnino-Díaz, 2008). These species are of great importance forming ecological corridors for bat migrations from the southeast to the northwest, as bats follow the flowering season's progression (Bustamante \& Búrquez, 2005; Bustamante et al., 2016). The above highlights the importance of studying population status, temporal ecology and the key bat habitat, particularly for migratory species such as lesser long-nosed bats (Leptonycteris yerbabuenae) along their migratory routes.

The species $L$. yerbabuenae is a migratory bat considered a priority for the maintenance of dry ecosystems dominated by columnar cacti (RojasMartínez et al., 2012). In Mexico, it is a species that migrates latitudinally along the Mexican Pacific coast from the northwest of Mexico and southwestern United States. This migration is linked to the flowering and fruiting season of columnar plants (Valiente-Banuet, 2002; Frick et al., 2018) that produce chiropterophilic flowers including Carnegiea gigantea, $P$. pringlei and S. thurberi (Valiente-Banuet, 2002). It is known that this species can move more than $50 \mathrm{~km}$ in one night towards the foraging area and maintain an activity of up to 7.5 hours and they always return to the same cactus patches due to the use of reinforcement learning (EgertBerg et al., 2018; Goldshtein et al., 2020).

Although the species seasonal ecology and population status has been extensively studied in central Mexico, little is known about its distribution in the northwest of the country (Frick et al., 2018). In the state of Sinaloa, studies on bat populations are scarce to nonexistent (Almazán-
La Sierra de Navachiste, localizada en el noroeste de México, está clasificada como un sitio Ramsar que forma parte de los polígonos tanto del sistema de lagunas MacapuleNavachiste-San Ignacio como del sistema de lagunas Santa María-Ohuira (Zavala-Norzagaray et al., 2007) y se considera una isla ecológica por estar rodeada de zonas donde se hace ganadería y otras actividades agrícolas.

En la región se han identificado 18 especies de cactus en islas y la zona continental, donde la vegetación dominante es Sternocereus thurberi y Pachycereus pectenaboriginum (Saturnino-Díaz, 2008). Estas especies son de gran importancia al formar corredores ecológicos para las migraciones de murciélagos del sureste al noroeste, ya que los murciélagos siguen la progresión de la temporada de floración (Bustamante \& Búrquez, 2005; Bustamante et al., 2016). Lo anterior destaca la importancia de estudiar el estado de la población, la ecología temporal y el hábitat clave de los murciélagos, particularmente para las especies migratorias como el murciélago magueyero menor (Leptonycteris yerbabuenae) a lo largo de sus rutas migratorias.

La especie L. yerbabuenae es un murciélago migratorio considerado prioritario para el mantenimiento de ecosistemas secos dominados por cactus columnares (Rojas-Martínez et al., 2012). En México, es una especie que migra latitudinalmente a lo largo de la costa del Pacífico mexicano desde el noroeste de México y el suroeste de Estados Unidos. Esta migración está relacionada con la temporada de floración y fructificación de las plantas columnares (Valiente-Banuet, 2002; Frick et al., 2018) que producen flores quiropterófilas como Carnegiea gigantea, Pachycereus pringlei y Stenocereus thurberi (Valiente-Banuet, 2002). Se sabe que esta especie puede moverse más de $50 \mathrm{~km}$ en una noche hacia el área de forrajeo y mantener una actividad de hasta 7.5 horas y siempre regresan a los mismos parches de cactus debido al uso del aprendizaje reforzado (Egert-Berg et al., 2018; Goldshtein et al., 2020).

Aunque la ecología estacional de la especie y el estado de la población se han estudiado ampliamente en el centro de México, se sabe poco sobre su distribución en el noroeste del país (Frick et al., 2018). En el Estado de Sinaloa, los estudios sobre poblaciones de murciélagos son escasos (Almazán-Catalán et al., 2015). Por lo tanto, se desconocen las necesidades ambientales, las amenazas actuales y los posibles impactos que enfrentan las poblaciones de murciélagos existentes (Hutson et al., 2001). 
Catalán et al., 2015). Therefore, the environmental needs, current threats and possible impacts facing the existing bat populations are unknown (Hutson et al., 2001).

This makes it difficult to determine the ecological role of these organisms and their role as keystone mutualist in the ecosystem (Hornet et al., 1998; Menchaca et al., 2020). Particularly, if the lesser long- nosed bat play a key role in the maintenance of biodiversity in dry environments of the region. Acquiring this knowledge is essential, especially in areas of ecological importance such as the Sierra de Navachiste protected area.

The purpose of this study was to identify and measure seasonal bat roost occupation and reproductive timing on the population of bats on the Sierra de Navachiste, Mexico, to assess the seasonal ecology.

\section{Methodology}

\section{Study area}

The Sierra de Navachiste is a natural protected area of state jurisdiction registered as an area subject to Ecological Conservation. It is classified as a Ramsar site forming part of the polygons for both the MacapuleNavachiste-San Ignacio lagoon system and the Santa MaríaOhuira lagoon system (Zavala-Norzagaray et al., 2007). The region has a territorial extension of 17,055 hectares, and is located between the municipalities of Guasave and Ahome, Sinaloa, Mexico, between geographic coordinates $25^{\circ} 27^{\prime} 10^{\prime \prime}$ and $25^{\circ} 36^{\prime} 30^{\prime \prime} \mathrm{N}, 108^{\circ} 48^{\prime} 05^{\prime \prime}$ and $109^{\circ} 05^{\prime}$ $00^{\prime \prime} \mathrm{W}$. This area presents characteristics that denote an ecological island, due to its geographical location as a small peninsula and the effects of anthropogenic activities such as agriculture, which isolates the Sierra de Navachiste from other natural areas (Figure 1).

During fieldwork, we identified a total of 15 caves, of which 14 held small populations of bats for only a few days, serving more as temporary shelters. Of the identified caves, only one had bat populations throughout the year. Furthermore, this site was chosen based on information collected through a citizen science project, with support from residents from the local fishing communities.

It was considered appropriate to focus efforts on the cave called "Cerro de Arena" due to its large size, the
Esto hace que sea difícil determinar el papel ecológico de estos organismos y su papel como mutualista clave en el ecosistema (Hornet et al., 1998; Menchaca et al., 2020). Particularmente si el murciélago magueyero menor juega un papel clave en el mantenimiento de la biodiversidad en los ambientes secos de la región, por lo que adquirir este conocimiento es fundamental, especialmente en áreas de importancia ecológica como el área protegida Sierra de Navachiste.

Por ello, el propósito de este estudio fue identificar y medir la ocupación estacional de los murciélagos y el tiempo de reproducción en la población de murciélagos en la Sierra de Navachiste, México, para evaluar la ecología estacional.

\section{Metodología}

\section{Área de estudio}

La Sierra de Navachiste es un área natural protegida de jurisdicción estatal registrada como área sujeta a Conservación Ecológica. Además, forma parte de dos sitios Ramsar formando parte de los polígonos del sistema de lagunas Macapule-Navachiste-San Ignacio y del sistema de lagunas Santa María-Ohuira (Zavala-Norzagaray et al., 2007). La región tiene una extensión territorial de 17.055 hectáreas, y se ubica entre los municipios de Guasave y Ahome, Sinaloa, México, entre las coordenadas geográficas $25^{\circ} 27^{\prime} 10^{\prime}$ 'y $25^{\circ} 36^{\prime} 30$ ' N, $108^{\circ} 48$ '05' ‘ y $109^{\circ} 05$ '00' 'O. Esta zona presenta características que denotan una isla ecológica, debido a su ubicación geográfica como una pequeña península y los efectos de actividades antropogénicas como la agricultura, que aísla a la Sierra de Navachiste de otras áreas (Figura 1).

Durante el trabajo de campo, se identificaron un total de 15 cuevas, de las cuales 14 albergaron pequeñas poblaciones de murciélagos durante sólo unos días, sirviendo más como refugios temporales. De las cuevas identificadas, solo una tenía poblaciones de murciélagos durante todo el año. Además, este sitio fue elegido con base en la información recopilada a través de un proyecto de ciencia ciudadana con el apoyo de los residentes de las comunidades pesqueras locales.

Se consideró oportuno enfocar esfuerzos en la cueva denominada "Cerro de Arena" debido a su gran tamaño y las poblaciones de murciélagos que alberga, además de ser considerada un sitio importante para la extracción de guano. La cueva está ubicada en las coordenadas $25^{\circ}$ $29^{\prime} 40.1$ " N y $109^{\circ} 04^{\prime} 31.82$ " O (Figura 1). 


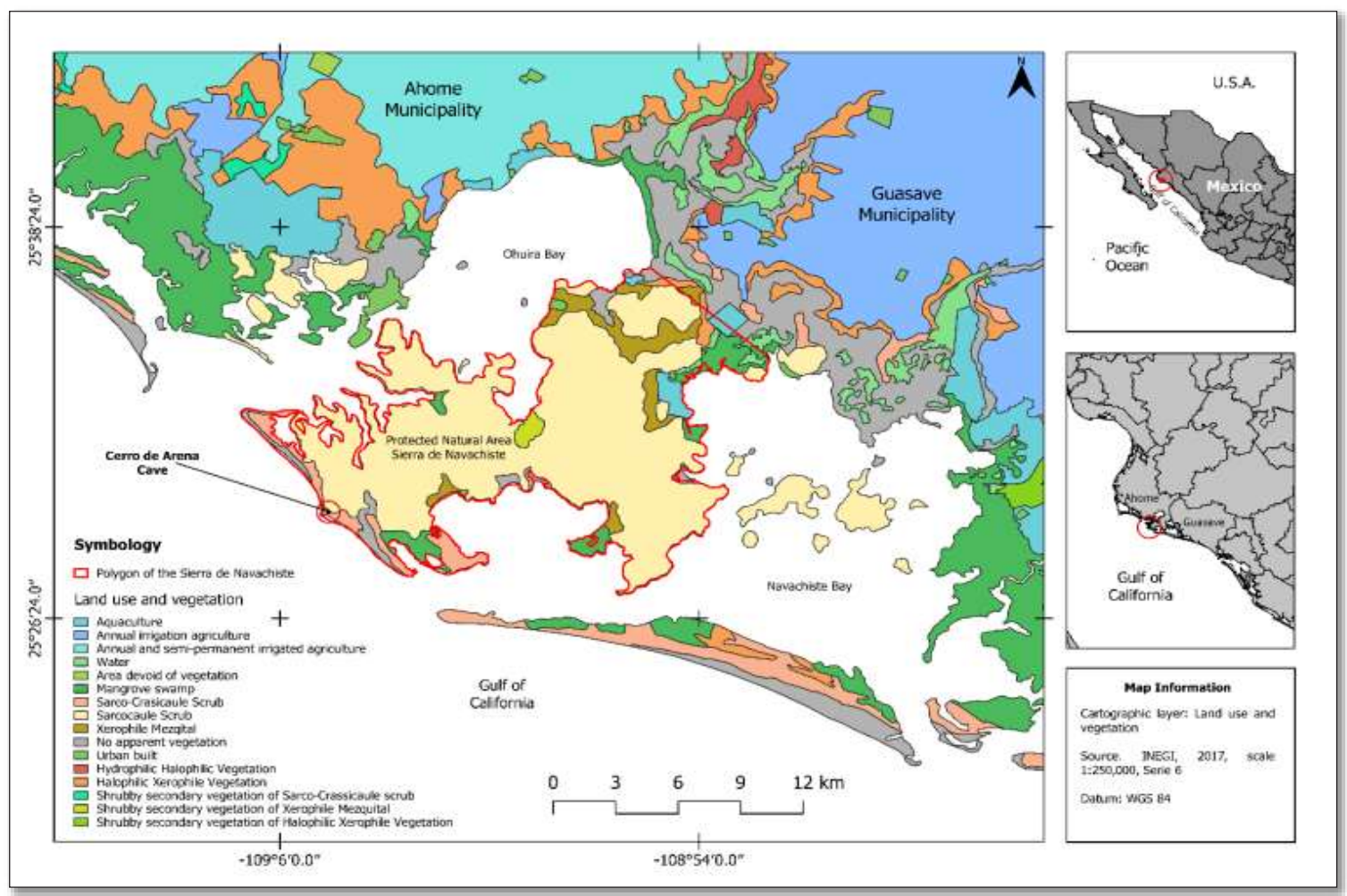

Figure 1. Sierra de Navachiste, Mexico.

Figura 1. Sierra de Navachiste, México.

composition of the bat community it houses, as well as being considered an important site for the extraction of guano. The cave is located at coordinates $25^{\circ} 29^{\prime} 40.1^{\prime \prime} \mathrm{N}$ and $109^{\circ} 04^{\prime} 31.82^{\prime \prime}$ W (Figure 1).

During the period 2012-2013 four nocturnal samplings were carried out in a lapse of $12 \mathrm{~h}$ (18:00 to 6:00 $\mathrm{h}$ ). One for each season of the year during the new moon period, to avoid the "Lunar phobia" syndrome, which is a behavior of evasion of the periods of greater brightness generated by the moon (Heithaus \& Fleming, 1978; Santos-Moreno et al., 2010).

Environmental conditions were also considered to easily access to the study site. Bats were captured by placing mist nets at dusk at the entrance of the cave. Nets were checked up every $30 \mathrm{~min}$. The bats were placed in cages until the data and samples were taken. Captured bats were identified to genus and species level, the life stage (pup, juvenile and adult), sex and trophic guild (Medellín et al., 2008) were also recorded. The handling was
Durante el periodo 2012-2013 se realizaron cuatro muestreos nocturnos en un lapso de $12 \mathrm{~h}$ (18:00 a 6:00 h). Uno por cada estación del año durante el período de luna nueva para evitar el síndrome de "fobia a la luna", que es un comportamiento de evasión de los períodos de mayor brillo que genera la luna (Heithaus \& Fleming, 1978; Santos-Moreno et al., 2010).

También se consideraron las condiciones ambientales para poder acceder fácilmente al sitio de estudio. Los murciélagos fueron capturados colocando redes de niebla al anochecer en la entrada de la cueva y se revisaron cada $30 \mathrm{~min}$. Los murciélagos fueron colocados en jaulas hasta que se tomaron los datos biométricos y las muestras. Los murciélagos capturados se identificaron a nivel de género y especie, la etapa de vida (cría, juvenil y adulto), también se registró el sexo y gremio trófico (Medellín et al., 2008). El manejo se llevó a cabo de acuerdo con los Procedimientos Operativos PREDICT: Métodos de muestreo de murciélagos (PREDICT Consortium, 2013) y con el permiso no. FAUT0250 de la Secretaría de Medio Ambiente y Recursos Naturales, México. 
carried out according to PREDICT Operating Procedures: Bat Sampling Methods (PREDICT Consortium, 2013) and under permission no. FAUT-0250 of the Secretaría de Medio Ambiente y Recursos Naturales, Mexico.

\section{Sampling sufficiency}

Diversity was estimated from the basic community data. The species richness (S) was determined as the total number of species observed, without considering its importance value. The relative abundance $(R)$, or the proportion of a species within the community, was obtained from the total number of individuals by species ( $n$ ) among the total number of individuals captured $(\mathrm{N})$ multiplied by 100 .

Morphometric data such as size $(\mathrm{mm})$ and weight (g) of the captured bats were presented as (mean \pm SD) followed by minimum and maximum intervals in parentheses (Min-Max).

Additionally, an accumulation curve was calculated using INEXT program (iNterpolation and EXTrapolation) to know whether the number of species found were representative with respect to the sampling effort made (JiménezValverde \& Hortal, 2003; Hsieh et al., 2016) (Figure 2).

Diversity and evenness of the bat community were determined using the indices of Shannon - Wiener $\left(H^{\prime}\right)$ and Simpson $(\lambda)$. Pielou index [J']) was used to measure the equitability between the diversity observed in relation to the maximum expected diversity ( $H^{\prime} \max$ ), being this the maximum possible value of $\mathrm{H}^{\prime}$ (if every species had the same evenness) (Moreno, 2001).

\section{Suficiencia de muestreo}

La diversidad se estimó a partir de los datos básicos de la comunidad. La riqueza de especies (S) se determinó como el número total de especies observadas, sin considerar su valor de importancia. La abundancia relativa $(R)$ o la proporción de una especie dentro de la comunidad se obtuvo del número total de individuos por especie $(n)$ entre el número total de individuos capturados (N) multiplicado por 100 .

Los datos morfométricos como el tamaño $(\mathrm{mm})$ y el peso (g) de los murciélagos capturados se presentaron como (media $\pm \mathrm{SD}$ ) seguidos de los intervalos mínimo y máximo entre paréntesis (Min-Max).

Adicionalmente, se calculó una curva de acumulación mediante el programa INEXT (interpolación y extrapolación) para saber si el número de especies encontradas era representativo con respecto al esfuerzo de muestreo realizado (Jiménez-Valverde \& Horta, 2003; Hsieh et al., 2015) (Figura 2).

La diversidad y uniformidad de la comunidad de murciélagos se determinaron utilizando los índices de Shannon-Wiener $\left(H^{\prime}\right)$ y Simpson $(\lambda)$. Se utilizó el índice de Pielou ( $J$ ') para medir la equidad entre la diversidad observada en relación con la diversidad máxima esperada (H'max), siendo este el valor máximo posible de $\mathrm{H}^{\prime}$ (si todas las especies tuvieran la misma uniformidad) (Moreno, 2001).

\section{Resultados}

La cueva "Cerro de arena" es la más grande y compleja de la Sierra de Navachiste, Sinaloa, con una

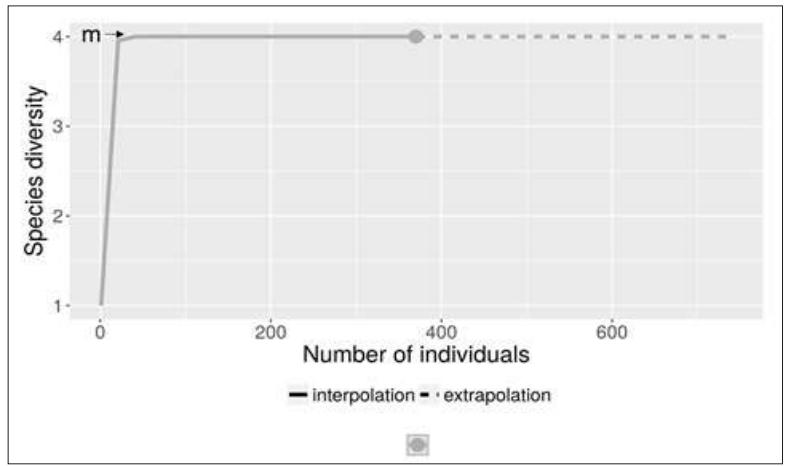

Figure 2. Species accumulation curve.

Figura 2. Curva de acumulación de especies. 


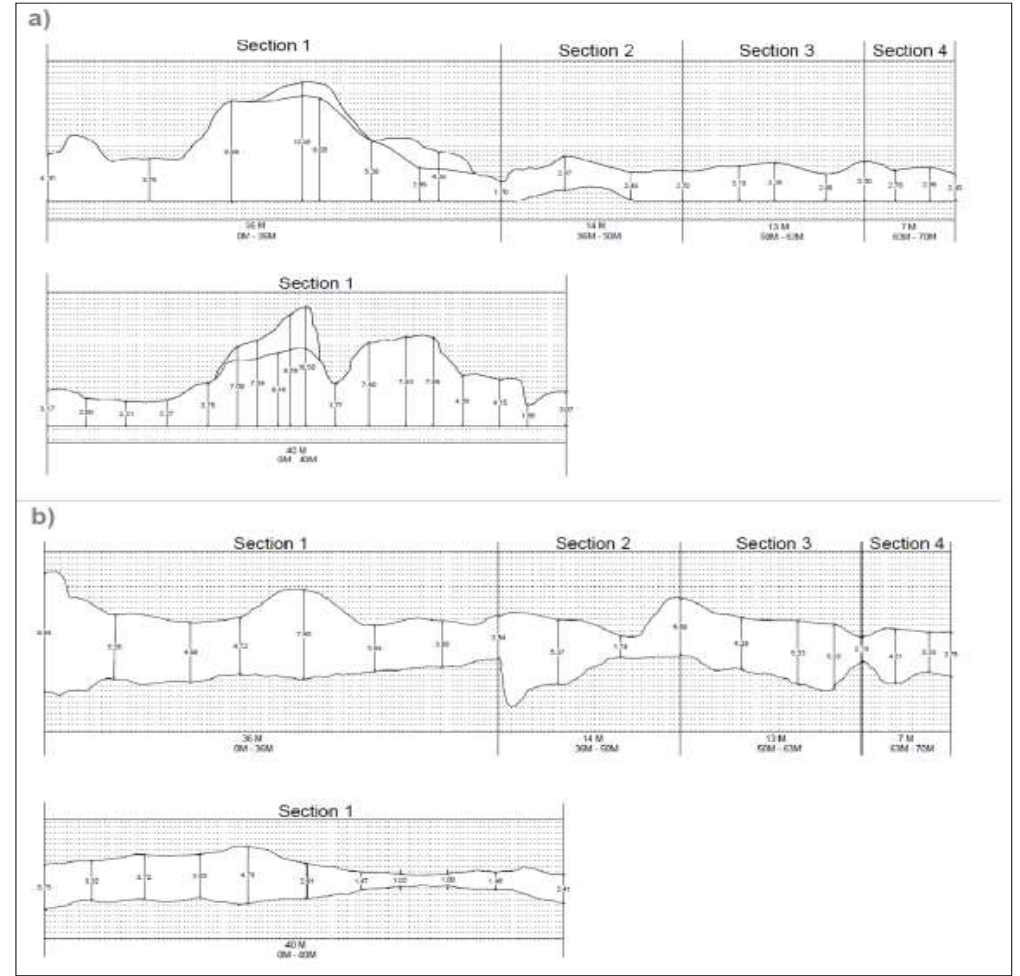

Figura 3. Medidas de la cueva Cerro de Arena. a). Vista lateral; b). Vista superior. Figure 3. Measurements of the cave Cerro de Arena. a). Side view; b). Top view.

\section{Results}

The cave "Cerro de arena" is the largest and most complex in the Sierra de Navachiste, Sinaloa, with an approximate distance to the sea of 340 meters. The cave has two entries and an approximate depth of $70 \mathrm{~m}$ (Figure 3).

The samplings were carried out per season between 2012-2013, to know the species richness, abundance, and diversity of bats. A species accumulation curve was made to know whether the identified bat species in the study area were representative of the sampling effort. It was estimated a total number of 41 bats per sampling effort (Figure 2). During each survey up to 71 bats were captured (Summer), therefore the sampling effort was enough to include all the species present in the study area.

Bats $(n=370)$ were captured belonging to three families and five species: Leptonycteris yerbabuenae $(n=205)$, Pteronotus psilotis $(\mathrm{n}=110)$, Macrotus californicus $(\mathrm{n}=29)$, distancia aproximada al mar de 340 metros. La cueva tiene dos entradas y una profundidad aproximada de $70 \mathrm{~m}$ (Figura 3).

Los muestreos se realizaron por estaciónentre 20122013 a fin de conocer la riqueza de especies, abundancia y diversidad. Se realizó una curva de acumulación de especies para saber si las especies de murciélagos identificadas en el área de estudio eran representativas del esfuerzo de muestreo. Se estimó un número total de 41 murciélagos por muestreo (Figura 2). Durante cada prospección se capturaron hasta 71 murciélagos (verano), por lo que el esfuerzo de muestreo fue suficiente para incluir todas las especies presentes en el área de estudio.

Se capturaron murciélagos $(n=370)$ pertenecientes a tres familias y cinco especies: $L$. yerbabuenae $(\mathrm{n}=205), P$. psilotis $(\mathrm{n}=110), M$. californicus $(\mathrm{n}=29), M$. megalophylla $(n=24)$ y $B$. plicata $(n=2)$. La mayor abundancia relativa de los organismos capturados ocurrió en primavera, 
Mormoops megalophylla $(\mathrm{n}=24)$ and Balantiopteryx plicata $(n=2)$. The highest relative abundance of the captured organisms occurred in spring, followed by autumn, summer and winter, respectively (Table 1 ). By species, $L$. yerbabuenae presented the highest percentage of bats captured throughout the year and during three seasons (spring, summer, and winter). However, P. psilotis was the most abundant species during autumn (Table 1). Of the total female bats collected, 29 were identified gestating and other 29 were lactating. The gestating individuals were $20 \mathrm{~L}$. yerbabuenae and nine P. psilotis. The lactating females were four $L$. yerbabuenae, two $P$. psilotis and one M. californicus. Table 1 presents the total bats captured by family and species, relative abundance, life stage and sex.

By sex, a higher proportion of females was observed compared to males over the study year. However, in spring, autumn and winter, the population was represented mainly by females, while in summer the proportion of male and female bats was similar. Of the total female bats (77), 20 were gestating and four lactating. The pregnant females were observed in winter and the lactating females in spring (Table 1). seguida de otoño, verano e invierno, respectivamente (Tabla 1). Por especies, L. yerbabuenae presentó el mayor porcentaje de murciélagos capturados durante todo el año y durante tres temporadas (primavera, verano e invierno). $P$. psilotis fue la especie más abundante durante el otoño (Tabla 1). Del total de murciélagos hembras recolectadas, 29 fueron identificadas en gestación y otras 29 en período de lactancia. Los individuos gestantes fueron 20 L. yerbabuenae y nueve $P$. psilotis. Las hembras lactantes fueron cuatro $L$. yerbabuenae, dos $P$. psilotis y una M. californicus. La Tabla 1 presenta el total de murciélagos capturados por familia y especie, abundancia relativa, etapa de vida y sexo.

Por sexo, se observó una mayor proporción de hembras durante el año de estudio ya que fueron dominantes en primavera, otoño e invierno, mientras que en verano el número de machos fue superior. Del total de murciélagos hembras (225), 29 se encontraban en gestación y siete lactantes (Tabla 1).

Por gremio trófico, se registró una especie de nectarívoro ( $L$. yerbabuenae), tres insectívoros aéreos ( $P$. psilotis $>M$. Megalophylla y $B$. plicata) y un insectívoro de sustrato $(M$. californicus) (Kalko et al., 1996).

Table 1.

Number of organisms captured, life stage and sex of Bats community from Navachiste, México, by annual season.

Tabla 1.

Número de organismos capturados, etapa de vida y sexo de las poblaciones de murciélagos de Navachiste, México, por temporada anual.

\begin{tabular}{|c|c|c|c|c|c|c|c|c|c|}
\hline \multirow{2}{*}{$\begin{array}{l}\text { Family } \\
\text { Specie } \\
\end{array}$} & \multicolumn{4}{|c|}{ Number of organisms captured } & \multirow{2}{*}{$\begin{array}{c}\text { Total } \\
\mathrm{J}\end{array}$} & \multicolumn{2}{|c|}{$\begin{array}{c}\text { Life } \\
\text { Stage }\end{array}$} & \multicolumn{2}{|c|}{ Sex } \\
\hline & Winter & Spring & summer & Annual & & A & M & $\mathrm{F}$ & \\
\hline \multicolumn{10}{|l|}{ Mormoopidae } \\
\hline Mormoops megalophylla & $13(15)$ & $11(20)$ & $0(0)$ & $0(0)$ & $24(6)$ & 0 & 24 & 10 & 14 \\
\hline Pteronotus psilotis & $49(56)$ & $12(22)$ & $20(13)$ & $29(41)$ & $110(30)$ & 50 & 60 & 43 & 67 \\
\hline \multicolumn{10}{|l|}{ Emballonuridae } \\
\hline Balantiopteryx plicata & $2(2)$ & $0(0)$ & $0(0)$ & $0(0)$ & $2(1)$ & 2 & 0 & 0 & 2 \\
\hline \multicolumn{10}{|l|}{ Phyllostomidae } \\
\hline Macrotus californicus & $15(17)$ & $6(11)$ & $2(1)$ & $6(8)$ & $29(8)$ & 4 & 25 & 15 & 14 \\
\hline Leptonycteris yerbabuenae & $8(10)$ & $26(47)$ & $135(86)$ & $36(51)$ & $205(55)$ & 112 & 93 & 77 & 128 \\
\hline Total & 87 & 55 & 157 & 71 & 370 & 168 & 202 & 145 & 225 \\
\hline
\end{tabular}

Note: Number of organisms captured followed by percentage of relative abundance in parentheses. Life Stage: (J) juvenile, (A) Adult; Sex: (M) Male, (F) Female.

Nota: Número de organismos capturados seguido del porcentaje de abundancia relativa entre paréntesis. Etapa de la vida: (J) juvenil, (A) adulto; Sexo: (M) Masculino, (F) Femenino. 
By trophic guild, we registered one Nectarivore species (L. yerbabuenae), three aerial insectivores $(P$. psilotis $>M$. Megalophylla and B. plicata) and one gleaning insectivorous (M. californicus) (Kalko et al., 1996).

With regard to species richness, the greatest number of species occurred in autumn, followed by winter, spring and summer, respectively. The bat $M$. megalophylla was the only species found in autumn and winter, while $B$. plicata was only found in autumn. Bat biodiversity in the Cerro de Arena cave, presented high annual diversity among the species present in the study area $\left(H^{\prime}=1.09 ; \lambda=0.59\right)$, which were evenly distributed $\left(J^{\prime}=0.68\right)$. By season, winter has the highest biodiversity indexes, and spring the lowest (table 2). Spring was the season with the lowest index among species, mainly characterized by L. yerbabuenae (Table 2).

It is important to mention that these species can share not only the same cave but also the same roost area, as has been observed with $M$. megalophylla, P. psilotis and L. yerbabuenae, using the same ledge areas. That said, L. yerbabuenae preferred the first chamber but were also observed during the breeding season in the central section of the cave, whereas bats of the genus Pteronotus also shared ledge area with other bat species. They preferred the second chamber of the cave and were not observed in the vaults of the first section.

Regarding species composition, L. yerbabuenae was the dominant bat species with 205 individuals captured during the study. The largest proportion of bats was captured during spring, followed by summer, winter, and autumn. Of the total captured organisms, juveniles were slightly more
En cuanto a la riqueza, el mayor número de especies se presentó en otoño, seguido del invierno, primavera y verano, respectivamente. La especie $M$. megalophylla fue encontrada únicamente en otoño e invierno, mientras que $B$. plicata sólo se encontró en otoño. La biodiversidad de murciélagos observada en la cueva Cerro de Arena fue de $H^{\prime}=1.09$ y $\lambda=0.59$, con una uniformidad de $\mathrm{J}^{\prime}=0.68$. Por estación, invierno presenta los índices de biodiversidad más altos, y primavera los más bajos (tabla 2). El motivo de que la diversidad en primavera sea menor se debe a la clara dominancia de $L$. yerbabuenae durante dicha estación (Tabla 2).

Es importante mencionar que estas especies pueden compartir no solo la misma cueva sino también la misma zona de descanso, como se ha observado con $M$. megalophylla, P. psilotis y L. yerbabuenae, utilizando las mismas áreas de descanso. $L$. yerbabuenae prefirió la primera cámara, pero también se observaron durante la temporada de reproducción en la sección central de la cueva, mientras que $P$. psilotis compartió el área de percha con otras especies de murciélagos, prefiriendo la segunda cámara de la cueva y no fue observada en las bóvedas de la primera sección.

En cuanto a la composición de especies, L. yerbabuenae fue la especie de murciélago dominante con 205 individuos capturados durante el estudio. La mayor proporción de murciélagos se capturó durante la primavera, seguida de otoño, verano e invierno. Del total de organismos capturados de esta especie, los juveniles fueron más abundantes que los adultos, debido a que en primavera se obtuvieron 111 juveniles y 24 adultos. Sin embargo, el resto de las estaciones los adultos fueron más abundantes.

Table 2.

Ecological component, diversity and evenness of the bats community from Navachiste, México by annual season.

Tabla 2.

Componente ecológico, diversidad y equidad de la comunidad de murciélagos de Navachiste, México por temporada anual.

\begin{tabular}{lccccc}
\hline Component & Autumn & Winter & Spring & summer & General \\
\hline Richness $(S)$ & 5 & 4 & 3 & 3 & $\mathbf{5}$ \\
Abundance $(R)$ & $24 \%$ & $15 \%$ & $42 \%$ & $19 \%$ & $\mathbf{1 0 0 \%}$ \\
Shannon-Wiener $\left(H^{\prime}\right)$ & 1.22 & 1.25 & 0.45 & 0.92 & $\mathbf{1 . 0 9}$ \\
Simpson $(\lambda)$ & 0.62 & 0.68 & 0.24 & 0.57 & $\mathbf{0 . 5 9}$ \\
\hline Pielou $\left(J^{\prime}\right)$ & 0.76 & 0.90 & 0.41 & 0.84 & $\mathbf{0 . 6 8}$ \\
\hline
\end{tabular}


abundant than adults. However, by season, adults were the most abundant in summer, autumn and winter, while in spring juveniles were up to two times more abundant than adults.

\section{Discussion}

Mexico is considered a megadiverse country in both animal and plant species. Studies on chiroptera richness in Mexico indicate that diversity is highest in the warmer and more humid states in the southern part of the country, e.g., Chiapas has 106 species (Retana \& Lorenzo, 2002) and Oaxaca 94 (García-García, 2006). Sinaloa, despite being a state that presents a dryer climate than those further souths, has 55 bat species (AlvarezCastañeda \& Patton, 1999).

Part of this species diversity was reported by EspericuetaViera (2012) in the Meseta de Cacaxtla, located between the municipalities of Mazatlán and San Ignacio, Sinaloa. The author reports 12 species and five families. The only species captured in our study that was absent in the Meseta de Cacaxtla was $M$. californicus. This may be explained due to the distribution of the species which southern limit is northern Sinaloa.

L. yerbabuenae is included on the IUCN red list (International Union for the Conservation of Nature) as a "vulnerable" species, and in Mexico it is listed within the NOM-059-SEMARNAT-2010 as a "Special protection" species. This bat is considered a "keystone mutualist species" due to its role within the ecosystem directly influencing the survival of other species through strong trophic relationships, which even influence the very structure of the ecosystem (Paine, 1995; Hornet et al., 1998; Menchaca et al., 2020). Notably, L. yerbabuenae has a mutualistic relationship with some cacti and agaves playing a key role in pollinating the columnar (Pachycereus pecten-aboriginum) and Pitahaya (Stenocereus thurberi) cacti that dominate the areas landscape. These species display a type of plant-pollinating interaction known as "pollination syndrome" (Bustamante \& Búrquez, 2005), which consists of a plant species producing only one type of flower that is only suitable for a particular pollinator species (Isasi-Catalá, 2001). Of all Mexican columnar cacti, $72 \%$ present this selective pollination syndrome (Valient-Banuet et al., 1996). On the other hand, the feeding habits of the bat $L$. yerbabuenae contribute to the scarification process which results when bats eat cacti fruits, helping soften the

\section{Discusión}

México es considerado un país megadiverso tanto en especies animales como vegetales. Los estudios sobre la riqueza de quirópteros en México indican que la diversidad es mayor en los estados más cálidos y húmedos del sur del país, por ejemplo, Chiapas cuenta con 106 especies (Retana \& Lorenzo, 2002) y Oaxaca con 94 (García-García, 2006). Sinaloa, a pesar de ser un estado que presenta un clima más seco, presenta 55 especies de murciélagos (Álvarez-Castañeda \& Patton, 1999).

Parte de esta diversidad de especies fue reportada por Espericueta-Viera (2012) en la Meseta de Cacaxtla, ubicada entre los municipios de Mazatlán y San Ignacio, Sinaloa. El autor reporta 12 especies y cinco familias. La única especie capturada en nuestro estudio que estuvo ausente en la Meseta de Cacaxtla fue M. californicus. Esto puede explicarse por la distribución de la especie cuyo límite sur es el norte de Sinaloa.

L. yerbabuenae está incluida en la lista roja de la IUCN (Unión Internacional para la Conservación de la Naturaleza) como especie "vulnerable", y en México figura dentro de la NOM-059-SEMARNAT-2010 como especie de "Protección Especial". Este murciélago se considera una "especie mutualista clave" debido a su papel dentro del ecosistema que influye directamente en la supervivencia de otras especies a través de fuertes relaciones tróficas, e influyen en la estructura misma del ecosistema (Paine, 1995; Hornet et al., 1998; Menchaca et al., 2020). En particular, $L$. yerbabuenae tiene una relación mutualista con algunos cactus y agaves jugando un papel clave en la polinización de los cactus columnares (Pachycereus pecten-aboriginum) y Pitahaya (Stenocereus thurberi) que dominan el paisaje de la zona. Estas especies muestran un tipo de interacción planta-polinización conocida como "síndrome de polinización" (Bustamante \& Búrquez, 2005), la cual consiste en una especie de planta que produce solo un tipo de flor que solo es adecuada para una especie polinizadora en particular (Isasi-Catalá, 2001). De todos los cactus columnares mexicanos, el $72 \%$ presenta este síndrome de polinización selectiva (Valient-Banuet et al., 1996). Por otro lado, los hábitos alimenticios del murciélago L. yerbabuenae contribuyen al proceso de escarificación que se produce cuando los murciélagos comen frutos de cactus, ayudando a ablandar la cubierta de la semilla en su tracto digestivo, y favorece su permeabilidad, y con ello, la captación de agua hacia las semillas acelerando la 
seed coat in their digestive tract, favoring its permeability, and with it, taking up water towards the seeds accelerating germination (Fleming et al., 1996; Bustamante \& Búrquez, 2005). It is important to emphasize that the cacti $P$. pectenaboriginum and $S$. thurberi are xenogames species unable to self-pollinate. Therefore, any reduction or loss in the population of $L$. yerbabuenae, would result in a decrease in the production of fruits of these cacti species and with this their decline in the ecosystem. However, L. yerbabuenae does not only feed on pollen, but also the fruit produced by these same species of cacti.

The bat $L$. yerbabuenae has a great flight capacity and given its migratory nature it may be the phylostomid with the longest flight distances, which indicates that its feeding sites are not necessarily close to its refuges (Medellín et al., 2018). Therefore, given their characteristics, they could completely cover the Sierra de Navachiste, pollinating and dispersing seeds throughout the area. However, further studies are needed to understand the role of this species in the pollination of cacti and the health of the floral ecosystem of the study area.

\section{Species richness}

The bat community of the "Cerro de Arena" cave was composed of five species. We recorded the presence of $L$. yebabuenae throughout the entire year and identified this population to be reproductively active. A breeding colony of $L$. yebabuenae has been previously identified in the Meseta de Cacaxtla, Sinaloa (Espericueta-Viera, 2012). However, we observed the complete reproduction cycle in Navachiste. Mating was recorded in summer and autumn, although in the latter season a smaller number of animals were captured. Winter was characterized by the capture of gravid females, and in spring, lactating females and a many offspring were collected $(n=111)$. In contrast to observations reported by Espericueta-Viera (2012), L. yebabuenae was found to present the same behavior in spring as that reported by the authors in November, although no offspring were reported. According to Ceballos et al. (1997), it seems to be two reproductive populations of $L$. yebabuenae in Mexico; one that gives birth in spring (February-May) and another in winter (November-January). Therefore, the reproductive population of Cacaxtla could be different from that found in the Sierra Navachiste.

\section{Abundance}

The relative and general abundance varied greatly throughout the year. This is probably due to bats germinación (Fleming et al., 1996; Bustamante \& Búrquez, 2005). Es importante destacar que los cactus $P$. pectenaboriginum y $S$. thurberi son especies de xenógamas incapaces de autopolinizarse. Por tanto, cualquier reducción o pérdida en la población de $L$. yerbabuenae, resultaría en una disminución en la producción de frutos de estas especies de cactus y con ello su declive en el ecosistema. Sin embargo, L. yerbabuenae no solo se alimenta de polen, sino también del fruto producido por estas mismas especies de cactus.

El murciélago L. yerbabuenae tiene una gran capacidad de vuelo y dada su naturaleza migratoria puede ser el filostómido con mayores distancias de vuelo, lo que indica que sus sitios de alimentación no necesariamente se encuentran cerca de sus refugios (Medellín et al., 2018). Por tanto, dadas sus características, podrían cubrir por completo la Sierra de Navachiste, polinizando y dispersando semillas por toda la zona. Sin embargo, se necesitan más estudios para comprender el papel de esta especie en la polinización de cactus y la salud del ecosistema floral del área de estudio.

\section{Riqueza de especies}

La comunidad de murciélagos de la cueva "Cerro de Arena" se compuso por cinco especies. Se Registró la presencia de $L$. yebabuenae durante todo el año e identificó a esta población como reproductivamente activa. Se ha identificado previamente una colonia reproductora de $L$. yebabuenae en la Meseta de Cacaxtla, Sinaloa (EspericuetaViera, 2012). Sin embargo, se observó el ciclo de reproducción completo en Navachiste. El apareamiento se registró en verano y otoño, aunque en la última temporada se capturó un número menor de animales. El invierno se caracterizó por la captura de hembras grávidas, y en primavera se recolectaron hembras lactantes y una gran cantidad de crías $(n=111)$. En contraste con las observaciones reportadas por EspericuetaViera (2012), L. yebabuenae presentó en primavera el mismo comportamiento que el reportado por los autores en noviembre, aunque no se reportó descendencia. De acuerdo a Ceballos et al. (1997), parece haber dos poblaciones reproductoras de L. yebabuenae en México; una que con alumbramientos en primavera (febrero-mayo) y otra en invierno (noviembre-enero). Por tanto, la población reproductora de Cacaxtla podría ser diferente a la encontrada en la Sierra Navachiste.

\section{Abundancia}

La abundancia relativa y general varió mucho a lo largo del año. Esto probablemente se deba a que los 
undertaking migrations due to climatic factors, food availability and reproductive needs. In Mexico, at least 25 of the 140 species exhibit migrational behavior (Medellín et al., 2008). We captured one migratory species in the Sierra de Navachiste: L. yerbabuenae and one regional seasonal migratory species: $M$. megalophylla (Schmidly \& Bradley, 2021). Yearly abundance varied with M. megalophylla, absent in summer due to regional movements. On the other hand, L. yerbabuenae was collected in the four seasons, although its abundance varied depending on the season. The population structure of this species changed drastically showing variations in the proportion of sexes and ages, as well as different physiological stages. This may be due to the migratory habit and the behavior of the species since the females form maternity caves where they give birth and nurse the young and juveniles, while the males inhabit other refuges (Haywar \& Cockrum, 1971). Therefore, in the summer and autumn samplings, males with scrotal testes were captured and the sex ratio (males / females) was 1.09 and 3 , respectively. In contrast in the winter, gestating females were captured, and in spring the proportion of lactating females and juveniles was 0.13 and 0.09 , respectively.

Studies on the species $L$. yerbabuenae commonly focus on northern regions of Mexico, from upper Sonora to the United States of America, where large refuges have been registered (Cole \& Wilson, 2006). However, geographic gaps exist in our knowledge of bat abundance, as highlighted by the case of Sinaloa. Other regions to the south also have records of $L$. yerbabuenae populations. For example, L. yerbabuenae is present year-round on the "Don Panchito" island in Jalisco (Stoner et al., 2003). Although the population varied in abundance, autumn and winter were the seasons with the largest number of individuals, while spring and summer had the lowest abundance of $L$. yerbabuenae. This contrasts with our findings from Sierra Navachiste, where the greatest abundance was in spring and summer. This reflects the migratory habits of this species with "Cerro de Arena" cave being a destination not just a stop off point during migration of bats from southern regions moving north. That said, further studies are needed on the migration and distribution of $L$. yerbabuenae in Mexico. The species $M$. californicus and $P$. personatus were present in all four seasons. In contrast, $B$. plicata was not captured in summer or winter. The total murciélagos realizan migraciones por factores climáticos, la disponibilidad de alimentos y las necesidades reproductivas. En México, al menos 25 de las 140 especies exhiben comportamiento migratorio (Medellín et al., 2008). Se capturó una especie migratoria en la Sierra de Navachiste: L. yerbabuenae y una especie migratoria estacional regional: M. megalophylla (Schmidly \& Bradley, 2021). La abundancia anual varió con $M$. megalophylla, ausente en verano debido a movimientos regionales. Por otro lado, $L$. yerbabuenae fue recolectada en las cuatro temporadas, aunque su abundancia varió según la temporada. La estructura poblacional de esta especie cambió drásticamente mostrando variaciones en la proporción de sexos y edades, así como diferentes estadios fisiológicos. Esto puede deberse al hábito migratorio y al comportamiento de la especie ya que las hembras forman cuevas de maternidad donde dan a luz y amamantan a las crías y juveniles, mientras que los machos habitan otros refugios (Haywar\& Cockrum, 1971). Así, en los muestreos de verano y otoño se capturaron machos con testículos escrotales y la proporción de sexos (machos/hembras) fue de 1,09 y 3 , respectivamente. En cambio, en invierno se capturaron hembras gestantes y en primavera la proporción de hembras lactantes y juveniles fue de 0,13 y 0,09 , respectivamente.

Los estudios sobre la especie $L$. yerbabuenae comúnmente se enfocan en las regiones del norte de México, desde el alto Sonora hasta los Estados Unidos de América, donde se han registrado grandes refugios (Cole \& Wilson, 2006). Sin embargo, existen brechas geográficas en el conocimiento de la abundancia de murciélagos, como el caso de Sinaloa. Otras regiones del sur de México también tienen registros de poblaciones de $L$. yerbabuenae. Por ejemplo, en la isla "Don Panchito" en Jalisco está presente todo el año (Stone et al., 2003). los autores señalan que la población varió en abundancia: el otoño y el invierno fueron las estaciones con mayor número de individuos, mientras que la primavera y el verano tuvieron la menor abundancia. Esto contrasta con nuestros hallazgos de Sierra Navachiste, donde la mayor abundancia fue en primavera y verano. Esto refleja los hábitos migratorios de esta especie, siendo la cueva "Cerro de Arena" un destino, no solo un punto de parada durante la migración de murciélagos de las regiones del sur que se desplazan hacia el norte. Dicho esto, se necesitan más estudios sobre la migración y distribución de $L$. yerbabuenae en México. Las especies $M$. californicus y $P$. personatus estuvieron presentes en las cuatro estaciones. Por el contrario, B. plicata no se capturó en verano ni en invierno. La abundancia total de B. plicata fue de solo tres individuos. De acuerdo con Berry et al. (2004) los murciélagos insectívoros tienen una alta 
abundance for $B$. plicata was just three individuals. According with Berry et al. (2004), the insectivorous bats have a high efficiency in the detection of mist nets and harp traps, which often leads to their absence on species lists. Based on this characteristic and the fact that $M$. californicus and $P$. psilotis had a higher abundance despite being insectivores, we can infer that the population of these species is higher within the cave, while $B$. plicata is found in a lower proportion.

The study area presented climatic temporality with a rainy season in summer followed by a pronounced dry season in winter, that influences the growth of the plants (Saturnino-Díaz, 2008). Ceballos et al. (1997) and Chávez \& Ceballos (2001) reported that these conditions affect the structure of the faunal communities. This was clearly observed through seasonal and temporal changes in bat community diversity.

The dry season presented a greater abundance; however, this result was influenced by the spring sampling in which 135 polinivorous bats were captured, of which 111 were juveniles and 24 adults. This high number of captured organisms coincides with peak flowering of many regional cacti species which provide higher nectar availability in relation to regions of lower latitudes during the dry season (Fleming et al., 2001). Although polinivorous species were most abundant during the dry season this shifted towards insectivorous species during the rainy season when they increased by $63 \%$ (114 organisms) compared to the summer and autumn dry season (70 organisms). This is a result of the increased abundance of insects during the rainy season due to increased plant growth and therefore food availability (Marco, 2001).

\section{Conclusion}

This is the first study on bat ecology undertaken at the Sierra de Navachiste in which three families and five species were identified: Emballonuridae (B. plicata), Mormoopidae ( $M$. megalophylla and $P$. psilotis) and Phyllostomidae (L. yerbabuenae and $M$. californicus). The identified species were divided into three trophic guilds: gleaning insectivores, aerial insectivores and pollinivores. The diversity of bats in the "Cerro de Arena" cave varied throughout the year. This variation was influenced by eficiencia en la detección de redes de niebla y trampas de arpa, lo que a menudo conduce a su ausencia en las listas de especies. Con base en ello y al hecho de que $M$. californicus y $P$. psilotis tuvieron una mayor abundancia a pesar de ser insectívoros, podemos inferir que la población de estas especies es mayor dentro de la cueva, mientras que $B$. plicata se encuentra en menor proporción.

El área de estudio presentó temporalidad climática con una estación lluviosa en verano seguida de una estación seca pronunciada en invierno, que influye en el crecimiento de las plantas (Saturnino-Díaz, 2008). Ceballos et al. (1997) y Chávez y Ceballos (2001) informaron que estas condiciones afectan la estructura de las comunidades de fauna. Esto se observó claramente a través de cambios estacionales y temporales en la diversidad de la comunidad de murciélagos.

La temporada seca presentó una mayor abundancia; sin embargo, este resultado fue influenciado por el muestreo de primavera en el que se capturaron 135 murciélagos polinívoros, de los cuales 111 eran juveniles y 24 adultos. Este alto número de organismos capturados coincide con el pico de floración de muchas especies de cactus regionales que proporcionan una mayor disponibilidad de néctar en relación con las regiones de latitudes más bajas durante la estación seca (Fleming et al., 2001). Aunque las especies polinívoras fueron más abundantes durante la temporada seca, esto se desplazó hacia las especies insectívoras durante la temporada de lluvias cuando aumentaron en un $63 \%$ (114 organismos) en comparación con la temporada seca de verano y otoño (70 organismos). Esto es el resultado de la mayor abundancia de insectos durante la temporada de lluvias debido al aumento del crecimiento de las plantas $\mathrm{y}$, por lo tanto, a la disponibilidad de alimentos (Marco, 2001).

\section{Conclusión}

Este es el primer estudio sobre ecología de murciélagos realizado en la Sierra de Navachiste en el que se identificaron tres familias y cinco especies: Emballonuridae (B. plicata), Mormoopidae (M. megalophylla y P. psilotis) y Phyllostomidae ( $L$. yerbabuenae y $M$. californicus). Las especies identificadas se dividieron en tres gremios tróficos: insectívoros de sustrato, insectívoros aéreos y polinívoros. La diversidad de murciélagos en la cueva "Cerro de Arena" varió a lo largo del año. Esta variación fue influenciada por la estacionalidad climática y la presencia de una especie 
climatic seasonality and the presence of one migratory species such as $L$. yerbabuenae and one species with regional movements such as $M$. megalophylla.

The study area has a breeding population of the species L. yerbabuenae, which is listed on the Mexican red list (NOM-059-SEMARNAT-2010) with the status of Special protection and in the IUCN red list as vulnerable. It is a keystone within the ecosystem due to its function as pollinator of the dominant columnar cacti as well as a disperser of its seeds though fruit consumption. This activity promotes the spreading of these plants and maintains the structure and health of the ecosystem.

Due to the importance of the Sierra Navachiste as a refuge for at least five bat species, including one migratory and protected species, it is necessary to establish a management plan in order to protect the chiroptera community that depends on it. migratoria como L. yerbabuenae y una especie con movimientos regionales como M. megalophylla.

El área de estudio cuenta con una población reproductora de la especie $L$. yerbabuenae, la cual figura en la lista roja mexicana (NOM-059-SEMARNAT-2010) con el estatus de Protección Especial y en la lista roja de la IUCN como vulnerable. Es una pieza clave dentro del ecosistema por su función como polinizador de los cactus columnares dominantes y como dispersor de sus semillas a través del consumo de frutos. Esta actividad promueve la propagación de estas plantas y mantiene la estructura y salud del ecosistema.

Debido a la importancia de la Sierra Navachiste como refugio de al menos cinco especies de murciélagos, incluida una especie migratoria y protegida, es necesario establecer un plan de manejo para proteger a la comunidad de quirópteros que depende de ella.

\section{References}

Almazán-Catalán, J. A., Sánchez-Hernández, C., Romero-Almaraz, M. de L., Sánchez-Vázquez, L., \& González-Pérez, S. B. (2015). Habitat use and reproduction of mammals from Tlaxmalac, at Balsas River basin, Guerrero, Mexico. The Southwestern Naturalist, 60(1), 36-44. https://doi.org/10.1894/JKF-44.1

Alvarez-Castañeda, S. T., \& Patton, J. L. (1999). Mamíferos del noroeste de México. Eds. Centro de Investigaciones Biológicas del Noroeste, La Paz, Baja California Sur, México. http://dspace.cibnor.mx:8080/bitstream/ handle/123456789/2910/Mamiferos\%20del\%20Noroeste\%20Vol1\%20Parte1. pdf? sequence=1\&isAllowed=y

Berry, N., O'connor, W., Holderied, M. W., \& Jones, G. (2004). Detection and Avoidance of Harp Traps by Echolocating Bats. Acta Chiropterologica, 6(2), 335-346. https://doi.org/10.3161/001.006.0211

Bustamante, E., Búrquez, A., Scheinvar, E., \& Eguiarte, L. E. (2016). Population Genetic Structure of a Widespread BatPollinated Columnar Cactus. PLOS ONE, 11(3), e0152329. https://doi.org/10.1371/journal.pone.0152329

Bustamante, E., \& Búrquez, A. (2005). Fenología y biología reproductiva de las cactáceas columnares. Cactáceas y Suculentas Mexicanas, 50(3), 68-88. https://biblat.unam.mx/es/revista/cactaceas-y-suculentas-mexicanas/ articulo/fenologia-y-biologia-reproductiva-de-las-cactaceas-columnares

Ceballos, G., Fleming, T. H., Chavez, C., \& Nassar, J. (1997). Population Dynamics of Leptonycteris curasoae (Chiroptera: Phyllostomidae) in Jalisco, Mexico. Journal of Mammalogy, 78(4), 1220-1230. https://doi.org/10.2307/1383065

Chávez, C., \& Ceballos, G. (2001). Diversidad y abundancia de murciélagos en selvas secas de estacionalidad contrastante en el oeste de México. Revista Mexicana de Mastozoología (Nueva Epoca), 5(1), 27. https://doi.org/10.22201/ ie.20074484e.2001.5.1.78

Cole, F. R., \& Wilson, D. E. (2006). Leptonycteris yerbabuenae. Mammalian Species, 797, 1-7. https://doi.org/10.1644/797.1

Egert-Berg, K., Hurme, E. R., Greif, S., Goldstein, A., Harten, L., Herrera M., L. G., Flores-Martínez, J. J., Valdés, A. T., Johnston, D. S., Eitan, O., Borissov, I., Shipley, J. R., Medellin, R. A., Wilkinson, G. S., Goerlitz, H. R., \& Yovel, Y. (2018). Resource Ephemerality Drives Social Foraging in Bats. Current Biology, 28(22), 3667-3673.e5. https:// doi.org/10.1016/j.cub.2018.09.064

Espericueta-Viera, J. C. (2012). Diversidad de murciélagos y sus nematodos parásitos en el área de protección de flora y fauna Meseta de Cacaxtla, Sinaloa, México. [Tesis de Maestría, Instituto Politécnico Nacional, Centro 
Interdisciplinario de Investigación para el Desarrollo Integral Regional, Unidad Sinaloa] . http://tesis.ipn.mx/ handle/123456789/13056

Fleming, T. H., Sahley, C. T., Holland, J. N., Nason, J. D., \& Hamrick, J. L. (2001). Sonoran Desert Columnar Cacti and the Evolution of Generalized Pollination Systems. Ecological Monographs, 71(4), 511. https://doi.org/10.2307/3100034

Fleming, T. H., Tuttle, M. D., \& Horner, M. A. (1996). Pollination Biology and the Relative Importance of Nocturnal and Diurnal Pollinators in Three Species of Sonoran Desert Columnar Cacti. The Southwestern Naturalist, 41(3), 257-269. http://www.jstor.org/stable/30055122

Frick, W. F., Heady, P. A., Earl, A. D., Arteaga, M. C., Cortés-Calva, P., \& Medellín, R. A. (2018). Seasonal ecology of a migratory nectar-feeding bat at the edge of its range. Journal of Mammalogy, 99(5), 1072-1081. https://doi. org/10.1093/jmammal/gyy088

Galindo-González, J. (1998). Dispersion de Semillas por Murcielagos: Su Importancia en la Conservacion y Regeneracion del Bosque Tropical. Acta Zoológica Mexicana (N.S.), (73), 57-74. https://doi.org/10.21829/azm.1998.73731727

García-García, J. L., Alfaro E., A. M., \& Santos-Moreno, A. (2006). Registros notables de los murciélagos en el estado de Oaxaca, México. Revista Mexicana de Mastozoología (Nueva Epoca), 10(1), 88-91. https://doi.org/10.22201/ ie.20074484e.2006.10.1.146

Goldshtein, A., Handel, M., Eitan, O., Bonstein, A., Shaler, T., Collet, S., Greif, S., Medellín, R. A., Emek, Y., Korman, A., \& Yovel, Y. (2020). Reinforcement Learning Enables Resource Partitioning in Foraging Bats. Current Biology, 30(20), 4096-4102.e6. https://doi.org/10.1016/i.cub.2020.07.079

Haywar, B. J., \& Cockrum, E. L. (1971). The natural history of the western long-nosed bat, Leptonycteris sanborni. Ed. Western New Mexico University Research in Science, Silver city, Nuevo Mexico.

Heithaus, E. R., \& Fleming, T. H. (1978). Foraging Movements of a Frugivorous Bat, Carollia perspicillata (Phyllostomatidae). Ecological Monographs, 48(2), 127-143. https://doi.org/10.2307/2937296

Horner, M. A., Fleming, T. H., \& Sahey, C. T. (1998). Foraging behaviour and energetics of a nectar-feeding bat, Leptonycteris curasoae (Chiroptera: Phyllostomidae). Journal of Zoology, 244(4), 575-586. https://doi.org/10.1017/ $\underline{\mathrm{S} 0952836998004105}$

Hsieh, T. C., Ma, K. H., \& Chao, A. (2016). iNEXT: an R package for rarefaction and extrapolation of species diversity (Hill numbers). Methods in Ecology and Evolution, 7(12), 1451-1456. https://doi.org/10.1111/2041-210X.12613

Hutson, A. M., Mickleburgh, S. P., \& Racey, P. A. (2001). Microchiropteran bats, Global status survey and conservation action plan. IUCN, Switzerland and Cambridge, UK. https://doi.org/10.2305/IUCN.CH.2001.SSC-AP.1.en

Isasi-Catalá, E. (2011). Los conceptos de especies indicadoras, paraguas, banderas y claves: su uso y abuso en ecología de la conservación. Interciencia, 36(1),31-38. https://www.redalyc.org/articulo.oa?id=33917727005

Jiménez-Valverde, A., \& Hortal, J. (2003). Las curvas de acumulación de especies y la necesidad de evaluar la calidad de los inventarios biológicos. Revista Ibérica de Aracnología, 8, 151-161. http://sea-entomologia.org/PDF/RIA 8/ R08-024-151.pdf

Kalko, E. K. V., Handley, C. O., \& Handley, D. (1996). Organization, Diversity, and Long-Term Dynamics of a Neotropical Bat Community. In Long-Term Studies of Vertebrate Communities (pp. 503-553). Elsevier. https://doi.org/10.1016/ B978-012178075-3/50017-9

Marco, V. (2001). Modelización de la tasa de desarrollo de insectos en función de la temperatura. Aplicación al Manejo Integrado de Plagas mediante el método de grados-día. Entomología Aplicada, 28(7):147-150. http://seaentomologia.org/PDF/BOLETIN_28/B28-038-147.pdf

Medellín, R. A., Arita, H. T., \& Sánchez, Óscar. (2008). Identificación de los murciélagos de México: Clave de campo. Universidad Nacional Autonoma de México, México, México. https://www.researchgate.net/publication/286335207 Identificacion de los murcielagos de Mexico_Clave_de campo_Segunda_Edicion_Instituto de_Ecologia

Medellin, R. A., Rivero, M., Ibarra, A., de la Torre, J. A., Gonzalez-Terrazas, T. P., Torres-Knoop, L., \& Tschapka, M. (2018). Follow me: foraging distances of Leptonycteris yerbabuenae (Chiroptera: Phyllostomidae) in Sonora determined by fluorescent powder. Journal of Mammalogy, 99(2), 306-311. https://doi.org/10.1093/jmammal/gyy016

Menchaca, A., Arteaga, M. C., Medellin, R. A., \& Jones, G. (2020). Conservation units and historical matrilineal structure in the tequila bat (Leptonycteris yerbabuenae). Global Ecology and Conservation, 23, e01164. https://doi. org/10.1016/j.gecco.2020.e01164 
Moreno, C. E. (2001). Métodos para medir la biodiversidad. MyT-Manuales y Tesis SEA, Primera Ed. CYTED. Zaragoza, España, 84 p. https://www.researchgate.net/publication/304346666 Metodos para medir la biodiversidad

Paine, R. T. (1995). A Conversation on Refining the Concept of Keystone Species. Conservation Biology, 9(4), 962-964. http://www.jstor.org/stable/2387008

PREDICT Consortium (2013). Protocol for Bat and Rodent Sampling Methods. https://manualzilla.com/doc/5990440/ protocol-bat-and-rodent-sampling-methods

Retana, O. G., \& Lorenzo, C. (2002). Lista de los mamíferos terrestres de chiapas: endemismo y estado de conservación. In Acta Zool. Mex. (n.s.) (Vol. 85). http://www.scielo.org.mx/scielo.php?script=sci arttext\&pid $=$ S0065-17372002000100003

Rivas-Camo, N. A., Sabido-Villanueva, P. A., Peralta-Muñoz, C. R., \& Medellin, R. A. (2020). Cuba in Mexico: first record of Phyllops falcatus (Gray, 1839) (Chiroptera, Phyllostomidae) for Mexico and other new records of bats from Cozumel, Quintana Roo. ZooKeys, 973, 153-162. https://doi.org/10.3897/zookeys.973.53185

Rojas-Martínez, A., Godínez-Alvarez, H., Valiente-Banuet, A., Arizmendi, Ma. del C., \& Sandoval Acevedo, O. (2012). Frugivory diet of the lesser long-nosed bat (Leptonycteris yerbabuenae), in the Tehuacán Valley of central Mexico. Therya, 3(3), 371-380. https://doi.org/10.12933/therya-12-94

Santos-Moreno, A., Ruiz Velásquez, E., \& Sánchez Martínez, A. (2010). Efecto de la intensidad de la luz lunar y de la velocidad del viento en la actividad de murciélagos filostómidos de Mena Nizanda, Oaxaca, México. Revista mexicana de biodiversidad, 81(3), 839-845. http://www.scielo.org. $\mathrm{mx/scielo.php?script=sci} \mathrm{arttext \& pid=S1870-}$ 34532010000300023\&lng=es\&tlng=es.

Saturnino-Díaz, J. (2008). Diversidad floristica y estructura de la vegetación de las islas de los sistemas lagunares Navachiste y Macapule del norte de Sinaloa. [Tesis de Maestría, Instituto Politécnico Nacional, Centro Interdisciplinario de Investigación para el Desarrollo Integral Regional, Unidad Sinaloa]. https://tesis.ipn.mx/ bitstream/handle/123456789/3802/DIVERSIDADFLORIS. pdf? sequence=1\&isAllowed=y

Schmidly, D. \& Bradley, R. (2021). Order Chiroptera-Bats. In The Mammals of Texas (pp. 110-216). New York, USA: University of Texas Press. https://doi.org/10.7560/308868-012

Secretaría de Medio Ambiente y Recursos Naturales [SEMARNAT]. (2010). NOM-059-SEMARNAT-2010. Lista de especies en riesgo de la Norma Oficial Mexicana NOM-059-SEMARNAT-2010, Protección ambiental-Especies nativas de México de flora y fauna silvestres-Categorías de riesgo y especificaciones para su inclusión, exclusión o cambioLista de especies en riesgo. Diario Oficial de La Federación. https://www.dof.gob.mx/nota detalle.php?codigo=5 $\underline{578808 \& \text { fecha }=14 / 11 / 2019}$

Simmons, N. B. \& Cirranello, A. L. (2020). Bat Species of the World: A taxonomic and geographic database. https://batnames. org.

Stoner, K. E., O.-Salazar, K. A., R.-Fernández, R. C., \& Quesada, M. (2003). Population dynamics, reproduction, and diet of the lesser long-nosed bat (Leptonycteris curasoae) in Jalisco, Mexico: implications for conservation. Biodiversity and Conservation, 12, 357-373. https://doi.org/10.1023/A:1021963819751

Valiente-Banuet, A. (2002). Vulnerabilidad de los sistemas de polinización de cactáceas columnares de México. Revista Chilena de Historia Natural, 75(1), 99-104. https://doi.org/10.4067/S0716-078X2002000100009

Valiente-Banuet, A., Arizmendi, M. D. C., Rojas-Martínez, A., \& Domínguez-Canseco, L. (1996). Ecological relationships between columnar cacti and nectar-feeding bats in Mexico. Journal of Tropical Ecology, 12(1), 103-119. https:// doi.org/10.1017/S0266467400009330

Vaughan, T. A., Ryan, J. M., \& Czaplewski, N. J. (2011). MAMMALOGY. 5th ed. Jones and Bartlett Publishers. Journal of Mammalogy, 92 (2), 15 478-479, https://doi.org/10.1644/imammal/92-2-478

Solari, S., \& Baker, R. J. (2007). Mammal species of the world: a taxonomic and geographic reference. Journal of Mammalogy, 88(3), 824-830. https://doi.org/10.1644/06-MAMM-R-422.1

Zachos, F. E. (2020). D. E. Wilson and R. A. Mittermeier (chief editors): Handbook of the Mammals of the World. Vol. 9. Bats. Mammalian Biology, 100(3), 335-335. https://doi.org/10.1007/s42991-020-00026-w

Zavala-Norzagaray, A. A., Briseño, R., Ramos, M., \& Aguirre, A. (2007). First record of juvenile olive ridley (Lepidochelys olivacea) in Northern Sinaloa Gulf of California, México. Procedings of the 27 Annual Symposium on Sea Turtle Biology and Conservation, Myrntle Beach, South Carolina. 